\title{
Design of Purchase-Sales-Inventory Business Software Based on Excel
}

\author{
Wang Shunjin \\ Accounting and Finance Department of Chongqing College of Electronic Engineering \\ Chongqing, China \\ Email: wangshunjin25@163.com
}

\begin{abstract}
Purchase-sales-inventory software is a common tool of small business enterprise information and can be designed by using Excel. This paper focuses on the idea of "fool" business software design with Excel sequence, record pointer and ActiveX control, and introduces the skills in invoking development tool, setting Macro security, using name and sequence, using Excel function, eliminating loop computation, designing record pointer, and designing "Reset" and "Confirm" control buttons in software design.
\end{abstract}

Keywords-Software design; ActiveX control; VBA code; record pointer; purchase-sales-inventory

\section{INTRODUCTION}

Purchase-sales-inventory software is a common tool for informationization of supermarkets, personal stores or other small enterprises. The author designs a "fool" purchase-sales-inventory software by using Excel. The operation method includes: firstly initially setting, inputting product information and initial data (see white region of Figure 1); inputting sales data (see white region of Figure 2), according to economic business, purchasing data (see white region of Figure 3); after clicking the "Confirm" button, automatically processing yellow-tinted region to generate information flow, such as purchasing and selling account (see Figure 4) by the software, automatically carrying over the cost of sales, calculating gross profit and generating purchase-sales-inventory quantity or amount of sub-species, etc.

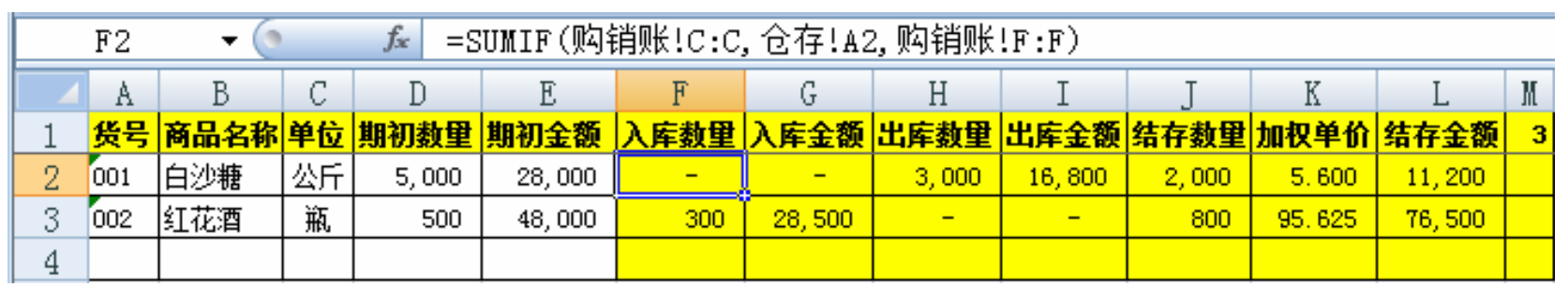

Figure 1. Inventory table

\begin{tabular}{|c|c|c|c|c|c|c|}
\hline$\underline{\underline{z}}$ & A & B & C & D & $\mathrm{E}$ & $\mathrm{F}$ \\
\hline 1 & \multicolumn{4}{|c|}{ 库存商品销售单 } & 重置 & 确认 \\
\hline 2 & 销货日期 & $2011-10-7$ & 客户 & \multicolumn{3}{|c|}{ 渝沙公司 } \\
\hline 3 & (1) 货号 & 商品名称 & 单位 & 销售数里 & 销售单价 & 销售金颖 \\
\hline 4 & 001 & 白沙糖 & 公斤 & 3,000 & 7 & 21,000 \\
\hline 5 & 加权成本 & 16,800 & 豠售成本 & & 销项悦楮 & 3,570 \\
\hline
\end{tabular}

Figure 2. Sales slip

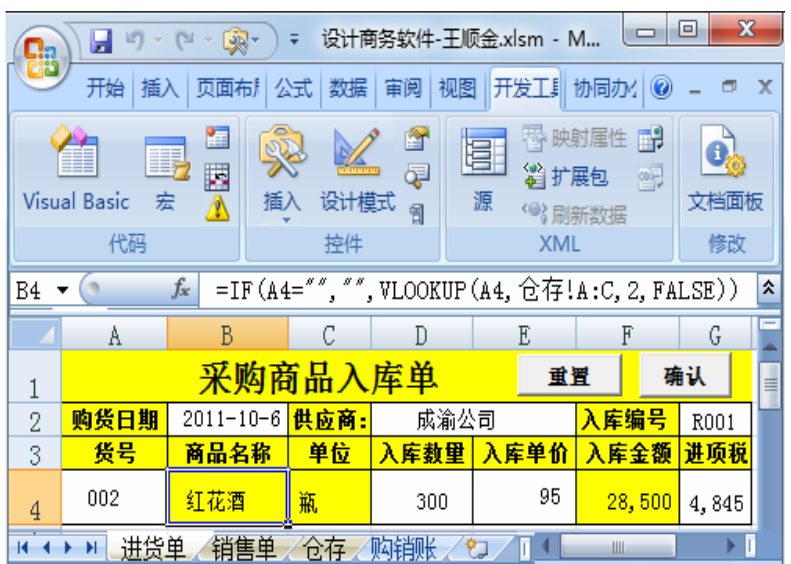

Figure 3. Purchase slip
Foundation item: Subject of China Commercial Accounting Institute in 2011, item number: China Commercial Institute Word [2011] No. 10 KJ201131 


\begin{tabular}{|c|c|c|c|c|c|c|c|c|c|c|c|c|}
\hline & L1 & $\checkmark$ & & $f_{x}=C$ & DUNTS & $(C: C)+$ & & & & & & \\
\hline & $\mathrm{A}$ & B & C & D & $\mathrm{E}$ & $\mathrm{F}$ & $\mathrm{G}$ & $\mathrm{H}$ & I & $\mathrm{J}$ & $\mathrm{K}$ & $\mathrm{L}$ \\
\hline 1 & 业务日期 & 往来单立 & 货号 & 商品名称 & 单位 & 入库数里 & 入库金楮 & 销售数里 & 㣯售收入 & 销售成本 & 销售毛利 & 4 \\
\hline 2 & $2011 / 10 / 6$ & 成渝公司 & 002 & 红花酒 & 瓶 & 300 & 28,500 & & & & - & \\
\hline 3 & $2011 / 10 / 7$ & 渝沙公司 & 001 & 白粮沙 & 公斤 & & & 3,000 & 21,000 & 16,800 & 4,200 & \\
\hline
\end{tabular}

Figure 4. Purchasing and selling account

\section{DESIGN OF FORM FIELD AND SEQUENCE}

\section{A. Invoking Excel development tool}

Click "Excel" button of "Office" button (see Figure 3) on the left upper corner of Excel interface, choose "Display Development Tool in Function Area" in "Commonly Use" type, and customize "Insert Control" button into Quick Toolbar ${ }^{[1]}$. Then, click " Macro-security" button, set to "Enable All Macro" (Excel2003 sets according to menu commands of "Tool/Macro/Security").

\section{B. Appearance setting and saving}

By right clicking the sheet tab on the bottom of Excel interface, the sheet is inserted, and the sheet tab is renamed to purchase slip, sales slip, inventory table, purchasing and selling account respectively, as shown in the bottom of Figure 3. Form text and table field name (bolded item No., product name, sales cost, input tax, trading profit, etc.) are entered into the 4 tables. The digital display format such as font, font style, font size, value and date or the like (the cell for displaying "Item No." should be set as "Text" format), fill color and border are set through the "Start" function area of Excel interface.

The file is saved as "Enable Macro Workbook (XLSM)" (Excel2003 saves as XLS).

\section{Use of name and sequence}

Select A4 cell in "sales slip (purchase slip)", click "Data Validity" in "data" function area, in "Setting" option, choose "ignore null value", provide drop down arrow, allow "sequence" originated from "=Item No."; choose "Stop" in "Error Warning" option, enter error information tip of "Choose item No., if the product is not available, newly building in the inventory table. By clicking A4 cell after setting, the drop down arrow as shown in Figure 2 will be displayed.

\section{DESIGN OF FUNCTION AND FORMULA}

\section{A. Use of common formula or function}

The trading profit in "purchasing and selling account" has the formula of K2=I2-J2. The balance in inventory table has the formula of $\mathrm{J} 2=\mathrm{D} 2+\mathrm{F} 2-\mathrm{H} 2$, $\mathrm{K} 2=\mathrm{L} 2 / \mathrm{J} 2, \mathrm{~L} 3=\mathrm{E} 3+\mathrm{G} 3-\mathrm{I} 3$. The sales amount in "sales slip" has the formula of F4=D4*E4. The incoming amount in "purchase slip" has the formula of F4=IF(OR(D4="'",E4="'),"',D4*E4), which means that if any D4 and E4 cell is empty, it disables the cell, otherwise, multiplying them. Note: The Excel formula forms one byte with punctuations such as brackets and double quotes and should be entered in English (two bytes in Chinese).

\section{B. Use of lookup and reference VLOOKUP function}

Select B4 cell in "sales slip (purchase slip)", enter nested function "=IF(A4="',"'",VLOOKUP(A4, Inventory!A:C,2,FALSE))" to Edit Toolbar as shown in Figure 3, which means that if A4 cell is empty, it disables the cell, otherwise, searching in columns A to C in "inventory table" the cells with the same values as those in A4 cell, and referencing the values in column two of the cell. ${ }^{[2]}$

Similarly, C4 cell in "sales slip (purchase slip)" has the formula of =IF(A4="'","',VLOOKUP(A4, Inventory!A:C,3,FALSE)). B5 cell in "sales slip" has the formula of =IF(OR(A4="',D4="'"),"',VLOOKUP(A4, Inventory!A:L,11,FALSE)*D4).

\section{Use of condition sum SUMIF function}

Select F4 cell in "inventory table", enter storage quantity formula "=SUMIF(Purchasing and selling account!C:C,Inventory!A2,Purchasing and selling account!F:F)" to Edit Toolbar, as shown in Figure 1, which means to find out in column $\mathrm{C}$ in "purchasing and selling account" the cells with the same values as those in A4 cell, and sum the values in column F of the cell in purchasing and selling account. Similarly, formulas of G2, H2, I2 of "inventory table" are set, such as G2=SUMIF(purchasing and selling account!C:C, inventory!A2, purchasing and selling account!G:G).

\section{Design of record pointer}

Select L1 cell in "purchasing and selling account", enter formula "=COUNTA(C:C)+1", which means to add 1 to non-empty cell in column C, with the effect of informing the software to write data in which row, as shown in Figure 4, which shows that "4" is to inform the software the data next confirmed should be filled in row 4 of the table. The pointer in "inventory table" has the formula of M1 =COUNTA(A:A).

\section{DESIGN OF "RESET" COMMAND BUTTON}

\section{A. Insert command button}

Select "purchase slip", click command button of "ActiveX Control" of "Insert" button in the development tool (Excel2003 sets according to the menu command of "View/Toolbar/Control Toolbox"), at this time when the mouse becomes "+" shaped, drag the button in E1 cell ${ }^{[3]}$. By right clicking the button to choose "Attribute" 
command, Caption is modified to "Reset", Font is modified to the fourth Song type, bolded font, Height is modified to 19.5, Left is modified to 204.

\section{B. Design of code for automatic operation of reset button}

Double click reset button of "purchase slip" to enter the VBA engineering interface, enter codes such as "Sheets("purchase slip").Cells $(4,1)=$ "'"', where " Cells $(4,1) "$ represents row 4 , column 1 , i.e., A4 cell. This means that if click the button, the values of A4 cell in the purchase slip will be emptied. The code for reset button is as shown in Figure 5.

\begin{tabular}{|c|c|c|}
\hline CommandButton1 & $\nabla$ & Cli ck \\
\hline 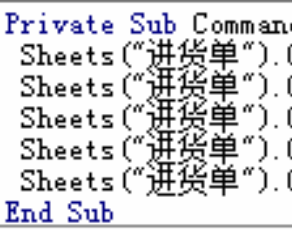 & $\begin{array}{l}\text { dBut } \\
\text { Cell } \\
\text { Cell } \\
\text { Cell } \\
\text { Cell } \\
\text { Cell }\end{array}$ & $\begin{array}{l}\text { on1_Click0 } \\
(2,2)=\cdots \\
(2,4)=\cdots \\
(4,1)=\cdots w \\
(4,4)=\cdots \cdots \\
(4,5)=\cdots\end{array}$ \\
\hline
\end{tabular}

Figure 5. Reset button code of purchase slip

It is only necessary to modify the "purchase slip" in the above code to "sales slip" when the reset button of "sales slip" is designed.

\section{DESIGN OF "CONFIRM" COMMAND BUTTON}

\section{A. Design of purchase slip confirm button}

Insert command button and set attribute, enter the code as shown in Figure after double click $^{[4]}$. IF, Else and End IF represent if, otherwise, and end hypothesis, MsgBox represents dialog box, and Dim i As Long represents that the variable $\mathrm{i}$ is a long integer data.

\begin{tabular}{|c|c|}
\hline CommandButton & Click \\
\hline 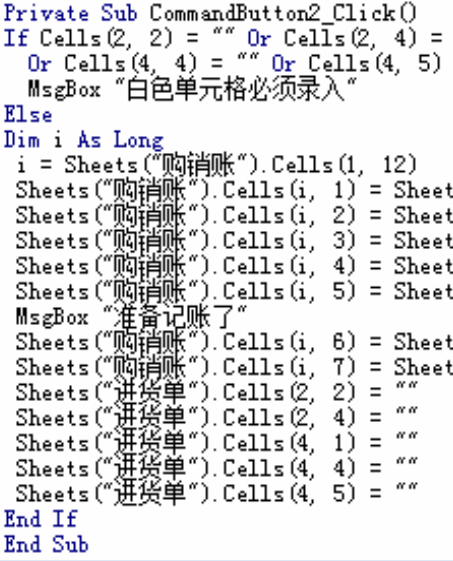 & 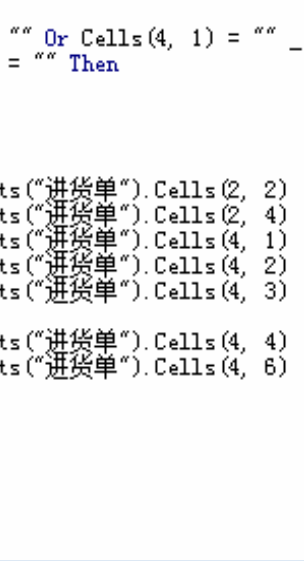 \\
\hline
\end{tabular}

Figure 6. Confirm button code of purchase slip

The figure illustrates that: if any of B2, D2, A4, D4, E4 cells is empty, popping up a dialog box of "White cell must be entered", otherwise, executing the following commands automatically. The i (long integer data) is defined as a value (i.e., the above-mentioned record pointer) of $\mathrm{L} 1$ cell in purchasing and selling account to determine which row the entered data should be saved (pointer row for short). The values of B2, B4, A4, B4, C4 cells in purchase slip are filled in 5 cells crossed between the pointer row of purchasing and selling account and columns A-E respectively. After the dialog box of "ready to keep accounts" pops up, the values of D4 and F4 cells in purchase slip are filled into two cells crossed between the pointer row and columns F and G. Finally, the values of B2, D2, A4, D4, E4 cells in purchase slip are emptied.

\section{B. Design of sales slip confirm button}

It is only necessary to modify the "purchase slip" in the above code to "sales slip" to design the previous code of "ready to keep accounts" of sales slip confirm button; rest codes are as shown in Figure 7.

The trading cost is automatically calculated with moving average method with the values of reference by referencing the values of cells in purchasing and selling account, if the table is refilled, it will be wrong due to loop computation, reference to the data source should be eliminated. The method is to refill after selectively pasting as value. The code automatically running is "Range("B5").Select......"(choose B5 cell). The part of code can be obtained by executing the method of "record macro" in the development tool (see Figure 3$)^{[5]}$.



Figure 7. Confirm button code of sales slip (last part)

The figure illustrates that: if a dialog box of "ready to keep accounts" pops up, the values of F4 cell in sales slip are filled in the cell crossed between the pointer row of purchasing and selling account and column I. If any of A4 and D4 cells is empty or 0 , the dialog box of "unable to carry out trading cost" pops up (to prevent deletion of original data caused by filling 0), otherwise, automatically executing the following codes. The B5 cell is chosen and copied, the D5 cell is chosen and selectively pasted as value, and the flash grid during 
copying is eliminated. The values of D4 and F4 cells in sales slip are filled in the two cells crossed between the pointer row of purchasing and selling account and columns $\mathrm{H}$ and J. Finally, the values of B2, D2, A4, D4, E4, D5 cells in sales slip are emptied.

\section{Hiding design code}

Column L in purchasing and selling account and column $\mathrm{M}$ in inventory table are design codes, which can be hidden during the use of software.

\section{CONCLUSION}

If the output tax and input tax in Figures 2 and 3 are set as fields in purchasing and selling account, they can be extended and perfected to "value added tax payable" detail account of the software. "Total amount", "payment received" and "bill receivable" are added to Figure 2. "Account receivable" module can be designed at this moment. By repeatedly extending the function and modifying the data linking relationship, you will find that it is similar to the function of the software such as UF-commerce, Shun and Tatsu software (housekeeper), housekeeper brilliant version usually used by current small enterprises. Related form fields are imported to database management software such as Access or SQL Server, and a man-machine interactive form is established, to design a "purchasing and selling account + automated financial (fool financial)" management system (simple Supply Chain Management Software).

\section{REFERENCES}

[1] J. Fu Jialin, Design of forecasting and decision experiment system based on Excel, China Management Informationization, 2010, 20, pp. 90-92

[2] J. Fu Yongping, Application of Excel function in power plant chemistry, China High-tech Enterprise, 2010, 10, pp. 46-48

[3] J. Song Yunfeng, VB student textual research system design based on Excel, Journal of Liaoning University of Petroleum and Chemical Technology, 2010, 4, pp. 8-9

[4] M. Wang Shunjin, Essence of Excel finance \& accounting application, Beijing: Beijing Institute of Technology Press, 2009, 9

[5] J. Wu Liyu, Application of Excel in student's grade list layout, Computer Programming Skills and Maintenance, 2011, 8, pp. 8-9 